\title{
Implementasi Misi Televisi Republik Indonesia: Antara Tanggung Jawab Sosial dan Kompetisi Media
}

\author{
Retor Aquinaldo Wirabuanaputera Kaligis, Nada Sofiyani, dan Cindy Clara \\ Fakultas Ilmu Komunikasi, Universitas Pancasila \\ retorawkaligis@univpancasila.ac.id
}

\begin{abstract}
In the midst of the development of private television stations and online media, TVRI is not only facing challenges in reaching audiences. Various private television programs and online media that are only pursuing profit have caused a number of excess to the social environment of the audiences. This study uses the Social Responsibility Press Theory linked with TVRI's mission as a public broadcasting institution. TVRI's mission illustrates that efforts to fulfill social responsibility must be placed in the context of media competition. If Public TV is not watched by many people, efforts to fulfill social responsibility will not have a significant impact on society. This research aims to determine the implementation of TVRI's mission in fulfilling the social responsibility of the press in the midst of media competition in the era of President Director Helmy Yahya (2017-2020). Using a descriptive qualitative approach and organization as the unit of analysis, this study used in-depth interview data collection techniques with a number of key informants and documentation. The results showed that the implementation of TVRI's mission was carried out through a number of breakthroughs, from the renewal of facilities and infrastructure to human resources. However, TVRI's efforts to fulfill social responsibility are constrained by regulatory factors and internal consolidation. Revision of Law no. 32 of 2002 is needed to reposition the supervisory board and independent financing for TVRI. Internal consolidation requires improving TVRI's internal administrative management, developing a new organizational culture, and strengthening the field of human resource management.
\end{abstract}

Keywords: audience; media competition; public service broadcasting; social responsibility of press; TVRI's Mission

\begin{abstract}
Abstrak
Di tengah perkembangan stasiun televisi swasta dan media online, TVRI tidak hanya menghadapi tantangan meraih khalayak. Berbagai program acara televisi swasta dan media online yang hanya mengejar keuntungan menimbulkan sejumlah ekses terhadap lingkungan sosial khalayak. Penelitian ini menggunakan Teori Pers Tanggung Jawab Sosial yang dikaitkan dengan misi TVRI sebagai lembaga penyiaran publik. Misi TVRI menggambarkan upaya pemenuhan tanggung jawab sosial harus diletakkan dalam konteks kompetisi media. Jika TV Publik tidak banyak ditonton orang maka upaya pemenuhan tanggung jawab sosial tidak berdampak signifikan di masyarakat. Penelitian ini bertujuan mengetahui implementasi misi TVRI dalam pemenuhan tanggung jawab sosial pers di tengah kompetisi media di era Direktur Utama Helmy Yahya (2017-2020). Dengan pendekatan kualitatif deskriptif dan organisasi sebagai unit analisis, penelitian ini menggunakan teknik pengumpulan data wawancara mendalam terhadap sejumlah informan kunci dan dokumentasi. Hasil penelitian menunjukkan implementasi misi TVRI dilakukan melalui sejumlah terobosan dari pembaruan sarana dan prasarana hingga sumber daya manusia. Namun upaya TVRI memenuhi tanggung jawab sosial terkendala faktor regulasi dan konsolidasi internal. Revisi UU No. 32 Tahun 2002 diperlukan untuk mereposisi kedudukan dewan pengawas dan kemandirian pembiayaan TVRI. Adapun konsolidasi internal memerlukan perbaikan manajemen administrasi internal TVRI, pengembangan budaya organisasi baru, dan penguatan bidang pengelolaan sumber daya manusia.
\end{abstract}

Kata kunci: khalayak; kompetisi media; lembaga penyiaran publik; misi TVRI; tanggung jawab sosial pers

Korespondensi: Dr. Retor Aquinaldo Wirabuanaputera Kaligis, M.Si., Fakultas Ilmu Komunikasi Universitas Pancasila, Jalan Srengseng Sawah, Jagakarsa, Jakarta Selatan-12640 Indonesia, Email: retorawkaligis@univpancasila.ac.id

Menyerahkan: Januari 2021, Diterima: Mei 2021, Terbit: Juli 2021

ISSN: 2549-0559 (cetak), ISSN: 2549-1946 (online), Website: http://jurnal.unpad.ac.id/kajian-jurnalisme 
Volume 05 Nomor 01 Tahun 2021

DOI: $10.24198 / j k j . v 5 i 1.31893$

\section{PENDAHULUAN}

Menjamurnya stasiun televisi swasta dan kehadiran media online tidak hanya membuat TVRI menghadapi tantangan untuk bersaing memperoleh khalayak. Sebagai lembaga penyiaran publik, TVRI memiliki tanggung jawab untuk memberikan arah bagi perkembangan positif di masyarakat. Perkembangan stasiun televisi swasta dan media online tidak hanya mengubah perilaku khalayak dalam bermedia, tapi juga konten-konten media yang hanya mengejar keuntungan memberikan sejumlah ekses terhadap lingkungan sosial khalayak.

Penelitian Centre for Innovation Policy and Governance (CIPG) dan HIVOS Asia Tenggara menunjukkan, penayangan sinetron gaya hidup beserta permasalahan metropolitan pada semua televisi di Indonesia merupakan proses tercerabutnya pemirsa dari kenyataan, terutama bagi kalangan yang tidak diuntungkan dan/atau berada di wilayah terpencil. Konvergensi media dapat memperburuk situasi itu, ketika tak hanya stasiun televisi yang mendangkalkan pemirsa dengan berbagai acara tidak mendidik, tetapi semua kanal media berkonten sama. Persoalan ini membuat media publik semacam TVRI dan RRI menjadi sangat penting untuk membentuk ranah publik di mana warga negara dapat menyuarakan pandangannya, ikut terlibat dalam interaksi sehat, atau memastikan pemenuhan hak warga negara dalam bermedia (Nugroho, Putri, \& Laksmi, 2012). Penelitian Septiantoro, Agus, Gultom, \& Octavian (2018) menunjukkan, perkembangan media komunikasi juga membuat masyarakat kesulitan memperoleh informasi valid yang terlihat dari banyaknya kasus fake news sehingga berdampak kepentingan negara dan stabilitas di masyarakat.

Sejak UU No.40 tahun 1999 diberlakukan, pers di Indonesia menganut teori pers tanggung jawab sosial di mana pers bertanggung jawab kepada masyarakat dan memberikan masyarakat kewenangan kontrol (Hutagalung, 2013). Prinsip tanggung jawab sosial pers kian lekat diemban oleh TVRI sebagai lembaga penyiaran publik yang bersifat independen, netral, dan tidak komersil yang berfungsi memberikan layanan untuk kepentingan masyarakat sebagaimana amanat UU No. 32 Tahun 2002 Pasal 14 ayat (1) dan (2).

Sebagai stasiun televisi pertama yang didirikan tahun 1962, TVRI menghadapi tantangan persaingan ketika stasiun televisi swasta hadir. TVRI ditinggal pemirsa generasi lama yang pernah menjadi saksi "kejayaan" stasiun televisi itu ketika tidak punya pesaing hingga akhir 1980-an. Generasi milenial dan generasi sesudahnya umumnya tidak pernah akrab dengan program-program acara TVRI. Generasi milenial lahir antara 1981 hingga 2000 (Young, Sturts, Ross, \& Kim, 2013), mereka menunjukkan keakraban yang lebih besar daripada generasi sebelumnya teknologi digital ini dan lebih terkoneksi dengan berbagai pilihan media online (Kaifi, Nafei, Khanfar, \& Kaifi, 2012).

Setelah Helmi Yahya diangkat menjadi direktur utama TVRI pada 2017, sejumlah terobosan dilakukannya, mulai dari pembaruan peralatan, tampilan layar dan grafis, inovasi program acara, peluncuran aplikasi android TVRI Klik, hingga pembenahan sumber daya manusia. Untuk menyasar kalangan milenial, TVRI membuat program seperti live music band indie dan acara komedi Ria Djenaka yang disajikan ala kekinian (Iswara, 2019).

Visi TVRI adalah menjadi lembaga penyiaran kelas dunia yang memotivasi dan memberdayakan, melalui program informasi, pendidikan dan hiburan yang menguatkan persatuan dan keberagaman guna meningkatkan martabat bangsa. Visi itu dituangkan dalam misinya yang terdiri dari enam poin (TVRI, 2019a). Pertama, menyelenggarakan program siaran yang terpercaya, memotivasi, dan memberdayakan yang menguatkan kesatuan dan keberagaman guna meningkatkan martabat bangsa. Kedua, mengelola sumber daya keuangan dengan tata kelola yang transparan, akuntabel dan kredibel, secara profesional, modern, serta terukur kemanfaatannya. Ketiga, menyelenggarakan penyiaran berbasis digital konvergensi 
dalam bentuk layanan multiplatform dengan menggunakan teknologi terkini, yang dikelola secara modern dan tepat guna, serta dapat diakses secara global.

Selanjutnya, keempat, menyelenggarakan tata kelola sumber daya manusia yang berkualitas, kompeten, kreatif dan beretika secara transparan berbasis meritokrasi, serta mencerminkan keberagaman. Kelima, menyelenggarakan tata kelola kelembagaan beserta tata kerjanya yang ramping dan dinamis, serta pengelolaan aset secara optimal dan tepat guna berdasarkan peraturan perundang-undangan. Keenam, mengoptimalkan pemanfaatan aset, meningkatkan pendapatan siaran iklan, dan usaha lain terkait penyelenggaraan penyiaran, serta pengembangan bisnis sesuai peraturan perundang-undangan. "Visi dan misi TVRI tersebut dicanangkan sejak 2017" (Wimbarti, Wawancara. 21 Mei 2020).

TVRI bermaksud menjadi lembaga penyiaran publik profesional. Namun sebagai TV Publik, khalayak TVRI harus dipandang sebagai publik atau warga negara (audience as public or citizen), berbeda dengan stasiun televisi swasta yang memandang khalayak sebagai konsumen atau pasar (audience as market). Memandang khalayak sebagai publik atau warga negara berarti melayani khalayak untuk mereformasi, mendidik, menginformasi, selain menghibur (Rachmiatie, 2006).

Detoni (2016) mengatakan, di era multiplatform distribusi konten, oligopoli sektor media, dan sifat transnasional industri budaya, Radio dan TV Publik perlu menemukan fungsi sosial baru yang membedakannya dengan media swasta dan membenarkan investasi negara di bidang komunikasi. Fungsi baru ini adalah penciptaan dan penguatan ruang publik media yang mendorong partisipasi warga dan tindakan transformatif.

Dengan menjadi lembaga penyiaran publik yang kuat dan berkualitas, TVRI tidak hanya bertujuan memperoleh tempat kembali di masyarakat Indonesia, juga memberi pengaruh lebih luas dalam menjalankan tanggung jawab sosialnya. Teori tanggung jawab sosial menganggap bahwa di dalam kebebasan mengandung suatu tanggung jawab yang layak. McQuail(2010) mengemukakan enam ciri teori pers tanggung jawab sosial yang menjadi prinsip utamanya. Pertama, media menerima dan memenuhi kewajiban tertentu dalam masyarakat. Kedua, kewajiban tersebut dipenuhi dengan standar yang tinggi atau profesionalitas tentang keinformasian, kebenaran, ketepatan, objektivitas, dan juga keseimbangan. Ketiga, sebaiknya saat menerima dan menerapkan kewajiban, media sudah harus mandiri dalam hal mengatur diri sendiri di dalam kerangka hukum serta lembaga yang ada. Keempat, media sebaiknya menghindari segala hal yang dapat menimbulkan kejahatan, kerusakan, atau ketidaktertiban umum atau penghinaan terhadap kaum minoritas etnik maupun juga agama. Kelima, media hendaknya bersifat pluralis dan mencerminkan kebinekaan, dengan memberikan kesempatan masyarakat untuk mengungkapkan berbagai sudut pandang dan hak untuk menjawab. Keenam, masyarakat memiliki hak untuk mengharapkan standar prestasi yang tinggi dan intervensi dalam hal ini dibenarkan untuk mengamankan kepentingan bersama.

Ravi (2012) menjelaskan kaitan independensi media dan tanggung jawab sosialnya. Media berfungsi sebagai cermin bagi penyimpangan masyarakat serta pekerjaan yang sesuai dengan kemajuan politik, sosial, dan budaya suatu bangsa. Media menjadi penjaga gerbang memperoleh pengetahuan, pendidikan, hiburan, dan kejadian di masyarakat. Independensi media terampas jika tanggung jawab sosial tidak menjadi bagian dari media massa.

Terdapat sejumlah penelitian mengenai kendala TVRI sebagai lembaga penyiaran publik. Firnandi (2017) menyoroti permasalahan TV Publik di Indonesia sebagian besar hampir sama dengan TV Publik di seluruh dunia, yakni bagaimana TV Publik dapat bertahan dalam persaingan media. BBC di Inggris menyiasiatinya dengan membuka portal berita online 33 bahasa, termasuk bahasa Indonesia. TV Publik di Eropa dan Amerika mengandalkan iuran 
masyarakat sehingga dituntut menjaga kualitas program acara. Penelitian Indriani, Fahmi, \& Yusuf (2017) terhadap kinerja Direktorat Pemberitaan TVRI menunjukkan rambu merah untuk semua indikator, yakni: perspektif keuangan, perspektif pelanggan, perspektif proses bisnis internal, serta perspektif pertumbuhan dan pembelajaran. Selanjutnya, penelitian De Fretes \& Kaligis (2018) mengulas persoalan ketidakmandirian TVRI untuk menjalankan tanggung jawab sosialnya tanpa adanya intervensi politik karena aturan-aturan yang ada membatasi ruang gerak TVRI. Budaya kerja yang masih mengikuti budaya PNS juga membuat TVRI sulit bersaing dengan televisi swasta. Adapun penelitian Masduki (2018) menyoroti keberadaan UU No 32 Tahun 2002 yang melemahkan keberadaan lembaga penyiaran publik.

Dari kajian terdahulu terlihat, tantangan kompetisi media dan upaya pemenuhan tanggung jawab sosial pers ibarat dua sisi mata uang yang diemban TV Publik. Jika TV Publik tidak mampu bersaing meraih khalayak dan tidak banyak ditonton orang maka upaya pemenuhan tanggung jawab sosial melalui program-program acara menjadi tidak berdampak signifikan di masyarakat. Misi TVRI sudah menggambarkan upaya pemenuhan tanggung jawab sosial harus diletakkan dalam konteks kompetisi media. Misi itu hendak diimplementasikan TVRI di era Direktur Utama Helmy Yahya. Dengan demikian, rumusan masalah penelitian adalah bagaimana implementasi misi TVRI dalam pemenuhan tanggung jawab sosial pers dan persaingan meraih khalayak di era Direktur Utama Helmy Yahya? Kendala apa saja yang dihadapi TVRI dalam mewujudkannya?

\section{METODE}

Penelitian ini menggunakan paradigma konstruktivisme yang memandang kebenaran suatu realitas sosial sebagai hasil konstruksi sosial. Peneliti menggunakan jenis penelitian deskriptif kualitatif dengan unit analisisnya adalah organisasi, yakni LPP TVRI.

Teknik pengumpulan data dilakukan dengan wawancara mendalam dan dokumentasi selama kurun Mei-Juni 2020. Informan kunci penelitian adalah Ketua KPI (Komisi Penyiaran Indonesia) Pusat, Agung Suprio; Direktur Program dan Berita TVRI, Apni Jaya Putra; Kepala Seksi Pemberitaan TVRI, Agil Samal; Anggota Dewan Pengawas TVRI, Supra Wimbarti; Direktur Penyiaran Kominfo, Geryantika Kurnia; dan mantan Anggota Komisi I DPR RI, Evita Nursanty. Dokumentasi yang digunakan UU No 40 tahun 1999 tentang Pers, UU No. 32 Tahun 2002 tentang Penyiaran, serta dokumentasi internal TVRI dan Direktorat Penyiaran Kominfo. Analisa data dilakukan dengan tahap reduksi data, penyajian data, dan penarikan kesimpulan. Penyajian data dibuat matriks untuk melihat keterkaitan pelaksanaan misi TVRI dan pemenuhan tanggung jawab sosialnya. Pemeriksaan keabsahan data menggunakan triangulasi sumber dan triangulasi teknik, di mana peneliti membandingkan hasil wawancara antar informan, kemudian dibandingkan dengan dokumentasi.

\section{HASIL DAN PEMBAHASAN}

\section{Implementasi Misi TVRI}

Misi TVRI pertama adalah penyelenggaraan program acara terpercaya, memotivasi, dan memberdayakan. TVRI memulai langkah menayangkan program-program acara yang disebut killer content agar masyarakat kembali menonton TVRI:

"Saya selalu berteori mem-progamming televisi itu ibarat ngelempar batu besar ke sungai. Splash-nya harus terasa. Kalau kamu bikin program kecil-kecil, splash-nya tuh hanya di situ. Kalau batu besar kan gak perlu banyak, satu dua orang terpercik ramai." (Putra, Wawancara. 9 Maret 2020)

Upaya TVRI itu diawali dengan kerja sama berbagai pihak mulai dari Discovery 
Channel, BWF (The Badminton World Federation), hingga TV Kabel Mola. Menurut Apni Jaya Putra, kerja sama dengan Discovery untuk meletakkan TVRI pada pergaulan internasional dan adanya kesamaan dengan TVRI di bidang ilmu pengetahuan. TVRI membeli 200 channel program Discovery dan memiliki kesempatan mendistribusikan beberapa program TVRI ke jalur distribusi Discovery. Adapun kerja sama dengan BWF dilatarbelakangi kegemaran masyarakat Indonesia akan tontonan bulu tangkis dan sejarah panjang TVRI terhadap tayangan bulu tangkis, tapi belakangan pindah ke stasiun lain. TVRI lalu berunding dengan BWF dan memperoleh lisensi 10 turnamen di awal dan 26 turnamen pada 2020. Dengan Mola TVRI mendapatkan lisensi menayangkan Liga Inggris sejak Agustus 2019. Brand Liga Inggris menjadi kebanggaan TVRI karena Liga Inggris memberikan kepada satu stasiun per negara (Putra, Wawancara. 9 Maret 2020).

Meski masyarakat mulai mengetahui upaya perubahan di TVRI, hanya beberapa program acara yang memiliki rating tinggi.

"Rating TVRI tinggi itu Liga Inggris, bukan program siaran lain. Kedua saat WFH (Work from Home) ada belajar di rumah program dari Kemendikbud, itu ratingnya tinggi. Discovery juga masih kecil. Intinya ada usaha perubahan dari TVRI untuk mengimbangi program siaran TV swasta, tapi belum signifikan menambah rating, kecuali Liga Inggris. Saya pakai data Nielsen.” (Suprio, Wawancara. 12 Juni 2020)

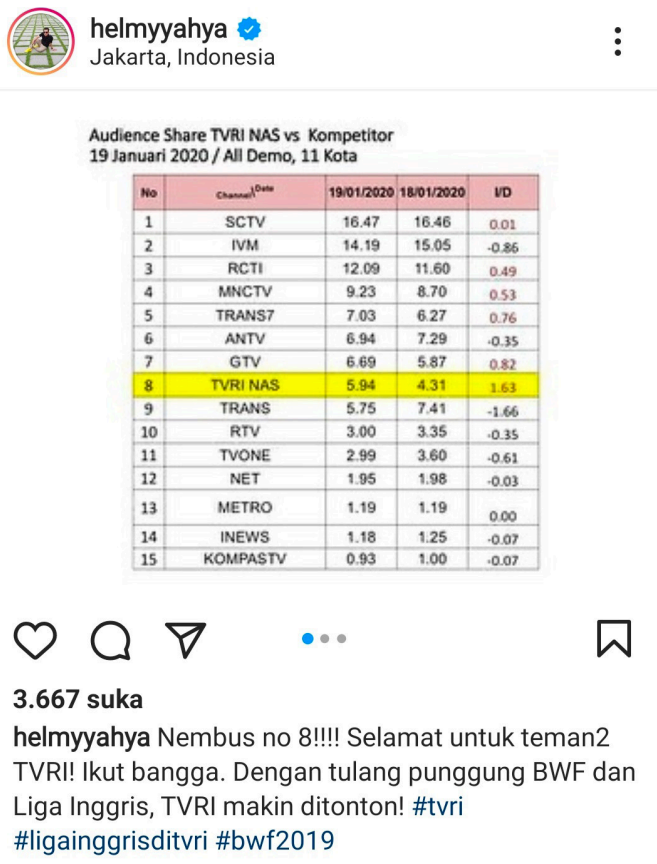

Gambar 1. Tangkapan Layar Instagram Helmy Yahya Sumber: Instagram @helmyyahya (2020)

Berdasarkan tangkapan layar Instagram Helmy Yahya pada 20 Januari 2020, Helmy mengutip data Nielsen di 11 kota bahwa audience share TVRI berada diurutan ke-8 per 19 Januari 2020. Pencapaian tersebut merupakan tertinggi sejak TVRI dipimpin Helmy Yahya. Meski begitu, tangkapan layar itu juga menunjukkan pengakuan Helmy bahwa kenaikan rating itu tak terlepas dari program tertentu, yakni BWF dan Liga Inggris.

Dengan demikian dapat dikatakan pemilihan program-program killer content menggambarkan keinginan TVRI memiliki acara informatif, edukatif, dan hiburan kelas berkualitas, serta membangkitkan rasa kebersamaan bangsa melalui tayangan olahraga favorit. Tapi splash dari killer content TVRI belum banyak menyebar ke program lain. 
Misi TVRI kedua berkaitan dengan tata kelola keuangan. Sebagai lembaga penyiaran publik, pengelolaan keuangan yang menggunakan dana APBN harus dipertanggungjawabkan kepada masyarakat.

"Kita mengelola apa yang disebut pembenahan dan akuntabilitas publik di tata kelola keuangan dan barang milik Negara. Tahun 2018 kita sudah menerima Wajar Dengan Pengecualian dan tahun 2019 kita Wajar Tanpa Pengecualian, dan menjadi juara dalam pengelolaan barang milik negara." (Putra, Wawancara. 9 Maret 2020)

Tapi tata kelola keuangan juga menjadi salah satu persoalan konflik direksi dan dewan pengawas yang berujung pemecatan Direktur Utama Helmy Yahya pada 16 Januari 2020. Surat No. 8/Dewas/TVRI/2020, yang ditandatangani Ketua Dewan Pengawas TVRI, Hidayat Thamrin menyatakan bahwa Helmy Yahya tidak menjawab atau memberi penjelasan mengenai pembelian program siaran berbiaya besar antara lain Liga Inggris dari pelaksanaan tertib administrasi anggaran TVRI. Dewan Pengawas TVRI juga menyoroti ketidaksesuaian pelaksanaan rebranding TVRI dengan rencana kerja yang ditetapkan dalam RKAT (Rencana Kerja Anggaran Tahunan) dan RKA-KL (Rencana Kerja Anggaran Kementerian/Lembaga) LPP TVRI. Pada 11 Mei 2020 Dewan Pengawas TVRI memberhentikan tiga direksi lain, yakni Direktur Program dan Berita, Apni Jaya Putra, Direktur Keuangan, Isnan Rahmanto dan Direktur Umum, Tumpak Pasaribu, dengan alasan sebagian besar pelanggaran Helmy Yahya melibatkan ketiga direksi itu.

Supra Wimbarti merupakan satu-satunya anggota Dewan Pengawas yang memberikan dissenting opinion terhadap pemecatan Helmy Yahya dan ketiga direksi TVRI. Menurutnya, tayangan Liga Inggris dan badminton bisa diperoleh TVRI berkat jaringan Helmy Yahya dan Apni Jaya Putra sehingga bisa memangkas harga menjadi sepertiga. Adapun dewan pengawas memandang itu sebagai sebuah kebijakan salah karena gagal bayar, menghamburkan uang negara, dan tidak ada akuntabilitasnya. Supra mengaku heran terhadap sikap dewan pengawas karena kontrak antara TVRI dan Mola bersifat multiyears (tahun jamak) (Wimbarti, Wawancara. 21 Mei 2020).

Dari konflik dewan pengawas dan dewan direksi terlihat bahwa belum ada standar baku tata kelola keuangan yang disepakati bersama pada internal TVRI, khususnya menyangkut RKAT dan RKA-KL. Upaya TVRI untuk transparan, akuntabel dan kredibel, secara profesional, modern serta terukur kemanfaatannya masih terbentur birokrasi internal.

Selanjutnya, misi ketiga TVRI adalah menyelenggarakan penyiaran berbasis digital dan multiplatform.

"Sekarang kita paling modern di seluruh televisi. Pemancarnya juga, ketika kita masuk kapasitasnya 30 kilowatt untuk Jakarta, kalau kapasitasnya penuh kadang-kadang cuma 10 kilowatt dibiarkan saja. Nah, kita langsung naikkan 100 kilowatt. Makanya Jakarta kinclong siaran TVRI-nya, apalagi digitalnya. Digitalnya kita 20 kilowatt dan pertumbuhan digitalnya kita paling cepat di antara stasiun lain. Coverage area itu kita di angka 89-90\%, kalau populasi barangkali sekarang hampir 80\%" (Putra, Wawancara. 9 Maret 2020). 
Kajian Jurnalisme

Volume 05 Nomor 01 Tahun 2021

DOI: $10.24198 / \mathrm{jkj} . v 5 \mathrm{i} 1.31893$

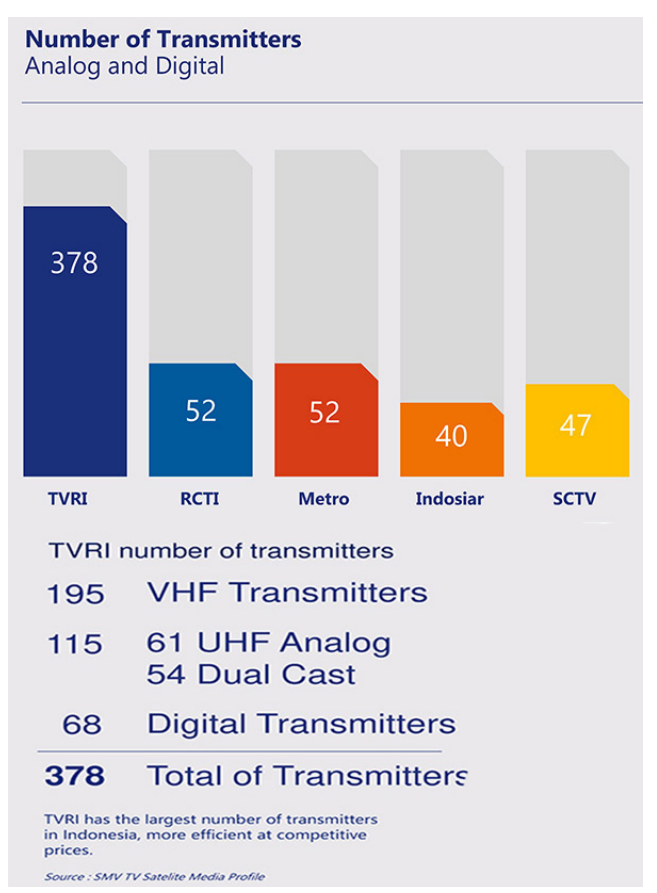

Gambar 2. Perbandingan jumlah transmisi TVRI dengan Stasiun TV Swasta

Sumber: TVRI Media Profile (TVRI, 2020)

Dari TVRI Media Profile (TVRI, 2020) pemancar digital TVRI berjumlah 68 buah. Total pemancar TVRI jauh di atas stasiun televisi swasta lainnya. Untuk menarik minat generasi milenial, TVRI berinovasi dengan meluncurkan aplikasi berbasis android bernama TVRI Klik. Dengan layanan streaming ini siaran TVRI dapat diakses pengguna yang sedang beraktivitas di dalam dan luar rumah di seluruh dunia. Terdapat 31 saluran di TVRI Klik, yakni TVRI Nasional, 28 kanal TVRI daerah, saluran budaya, dan saluran olah raga.

"TVRI Klik itu dulu 2000 orang nonton kolaps. Sekarang saya pasang CDN (Content Delivery Network) berbasis Cloud. Sekarang mau nonton dua juta, dua puluh juta, dia nggak putus. Itu kemajuan yang kita buat dari sisi lini OTT (Over The Top) layer-nya." (Putra, Wawancara. 9 Maret 2020)

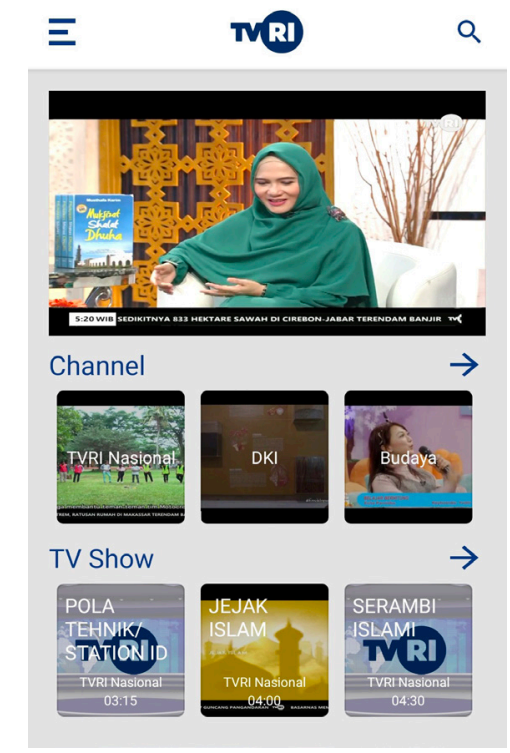

Gambar 3. Tampilan TVRI Klik

Sumber: Screenshot Aplikasi TVRI Klik (2020)

Implementasi Misi Televisi Republik Indonesia: Antara Tanggung Jawab Sosial dan Kompetisi Media (Retor Aquinaldo Wirabuanaputera Kaligis, Nada Sofiyani, dan Cindy Clara) 
Namun berdasarkan pengamatan peneliti pada play store di android, TVRI Klik baru diunduh 1 juta kali lebih sampai akhir Mei 2021, jadi belum teruji puluhan juta orang melakukan streaming TVRI Klik secara berbarengan. KPI menilai positif aplikasi TVRI Klik untuk menjangkau khalayak, terutama generasi milenial yang mobilitas sehari-harinya akrab dengan smartphone. Tapi TVRI dipandang bukan pionir karena RRI sebagai sesama lembaga penyiaran publik sudah menggunakan aplikasi untuk layanan streaming siarannya (Suprio, Wawancara. 12 Juni 2020).

Dapat dikatakan upaya TVRI melakukan penyiaran berbasis digital sudah berjalan baik sehingga kualitas siaran dan daya jangkaunya meningkat tajam. Untuk siaran streaming, meski bukan pionir tapi TVRI memiliki keunggulan siarannya bersifat audio-visual.

Misi keempat TVRI berkaitan dengan tata kelola SDM di bidang pertelevisian.

"TVRI selama 15 tahun tidak menerima karyawan baru. ketika saya masuk 72 persen karyawan berusia 42-45 tahun ke atas. Lembaga kreatif butuh banyak anak muda untuk mendorong perubahan, jadi kita mulai meminta negara memikirkan ini...Setidaknya kita ketambahan 600-an orang dari kebutuhan sekitar 1300 orang karena pensiun dan lain-lain." (Putra, Wawancara. 9 Maret 2020)

Perubahan komposisi karyawan yang mulai diisi banyak tenaga muda berdampak pada perubahan suasana kerja dan kualitas program acara TVRI. Agil Samal menilai, tenaga muda itu mempunyai semangat tinggi sehingga lebih mudah mengarahkannya untuk sebuah perubahan. Ia mengambil contoh program dokumenter Jelajah Kopi yang dikerjakan para tenaga muda TVRI mengalahkan program sejenis Kompas TV (Samal, Wawancara. 11 Mei 2020).

Tapi TVRI masih memiliki kendala untuk meningkatkan kesejahteraan dan pengembangan diri karyawan.

"Ada kaitannya dengan budget, terutama untuk peningkatan SDM. Kalau menurut saya, SDM TVRI itu mohon maaf tidak bagus. Sudah lama pendidikan, terlebih lulusan degree program nggak pernah diurusin. Dulu degree program dilatih di Perancis 6 bulan dan sebagainya, sekarang tidak ada lagi." (Wimbarti, Wawancara. 21 Mei 2020)

Dapat disimpulkan, TVRI sudah merombak komposisi karyawan yang diisi generasi muda kreatif. Tapi faktor kesejahteraan dan pengembangan diri karyawan membuat anak-anak muda yang sudah direkrut sulit diharapkan bertahan mengembangkan TVRI dalam jangka menengah dan panjang. Padahal para karyawan muda merupakan produk reformasi TVRI di zaman Helmy Yahya sehingga menjadi masa depan TVRI untuk melanjutkan perubahan. "Mereka harus segera ditanamkan corporate culture yang baru. Kalau nggak kena virus orangorang lama" (Wimbarti, Wawancara. 21 Mei 2020).

Selanjutnya, misi kelima TVRI berkaitan dengan tata kelola kelembagaan, tata kerja, dan pengelolaan aset. Upaya TVRI menjangkau seluruh wilayah Indonesia perlu didukung teknologi pertelevisian yang up date.

"Saya kesini tripod-nya diganjal pakai kayu, dengan kamera tahun 2000, ada yang masih tahun 98, kamera yang "dinosaurus" itu. Sekarang kita pakai kamera Ikegami seri 9, industri TV swasta masih seri 5 dan seri 7, jadi kita the latest. Semua peralatan sudah menggunakan teknologi 4K." (Putra, Wawancara. 9 Maret 2020)

Upaya pembaruan dan pengembangan TVRI untuk meningkatkan kualitas tayangan memiliki catatan dalam hal tata kelola kelembagaan. Supra Wimbarti menjelaskan, segi positif TVRI di era Direktur Utama Helmy Yahya adalah progresif di dalam perbaikan image TVRI di publik. Tetapi mereka agak kedodoran dalam hal administrasi, check and recheck dengan regulasi yang ada. Menurutnya, direksi di era tersebut tidak salah, tapi lemah dalam hal itu (Wimbarti, Wawancara. 21 Mei 2020). 
Dengan demikian, dalam misi kelima TVRI di era Helmy Yahya memiliki keunggulan di depan layar. Kemampuannya mengelola aset secara optimal dan tepat guna meningkatkan kualitas tayangan secara teknis dan isi acara. Tapi di belakang layar, kelemahan dalam manajemen administrasi perlu diperbaiki karena sebagai lembaga penyiaran publik TVRI terikat rambu-rambu aturan dan birokrasi yang berbeda dengan stasiun TV swasta.

Konflik dewan pengawas dan dewan direksi tidak terlepas dari persoalan aturan dan birokrasi. UU No. 32 Tahun 2002 Pasal 14 Ayat (5) menyebutkan Dewan pengawas ditetapkan oleh Presiden bagi Radio Republik Indonesia dan Televisi Republik Indonesia atas usul Dewan Perwakilan Rakyat Republik Indonesia. Pada Ayat (7) dinyatakan dewan direksi diangkat dan ditetapkan oleh dewan pengawas. Dengan aturan tersebut, kedudukan dewan pengawas lebih kuat ketimbang dewan direksi dan potensial menimbulkan konflik struktural karena dewan pengawas mengawasi kerja direksi dan dewan direksi disibukkan urusan birokrasi internal.

Misi keenam menyangkut pemanfaatan aset dan bisnis. Pengoptimalan pemanfaatan aset dilakukan melalui berbagai kerja sama dengan pihak lain, antara lain Discovery Channel untuk distribusi program dan partnership. UU No. 32 Tahun 2002 Pasal 15 ayat (1) menyatakan sumber pembiayaan Lembaga Penyiaran Publik berasal dari iuran penyiaran, APBN atau APBD, sumbangan masyarakat, siaran iklan, dan usaha lain yang sah. Selama ini TVRI lebih mengandalkan APBN sehingga berdampak pada kemandirian keuangan TVRI.

"TVRI saya kira tidak akan mandiri kalau bergantung pada APBN seratus persen, mestinya diubah bahwa iuran publik itu menjadi tulang punggung pembiayaan. Undangundangnya memungkinkan adanya iuran publik tapi tidak juga dibuat juklaknya. APBN itu posturnya $60 \%$ fix cost, sisanya untuk kepentingan program dan pembelian peralatan. Anggaran saya Rp 162 Miliar pertahun, itu sama saja anggaran RCTI selama satu bulan. Politik anggaran pemerintah menunjukkan keberpihakan. Korea Selatan dititipkan pada listrik. BBC 88 Triliun dan NHK 90 Triliun, semuanya dari dana publik. Akibatnya tidak ada independensi dalam hire and fire karyawan, di sini bukan karyawan TVRI, mereka ini kan semua karyawan Kominfo. Kalau iklan harganya dipatok fix 2 juta per slot enggak boleh lebih, tidak ada time zone. Kalau saya jual semua slot iklan total setahun cuma Rp 284 Miliar. Artinya, TVRI tidak dibuat untuk komersial. Saya setuju tidak dibuat komersial tapi pemerintah harus mencari instrumen pembiayaan yang baru, iuran publik." (Putra, Wawancara. 9 Maret 2020)

\begin{tabular}{|c|c|c|c|c|}
\hline Aspek & $\begin{array}{c}\text { BBC } \\
\text { Inggris }\end{array}$ & $\begin{array}{c}\text { NHK } \\
\text { Jepang }\end{array}$ & $\begin{array}{c}\text { ABC } \\
\text { Australia }\end{array}$ & $\begin{array}{c}\text { TVRI } \\
\text { Indonesia }\end{array}$ \\
\hline Kelembagaan & \begin{tabular}{|l} 
100\% Milik \\
Publik \\
Bertanggung \\
Jawab Kepada \\
Ratu
\end{tabular} & $\begin{array}{l}100 \% \text { Milik } \\
\text { Publik } \\
\text { Bertanggung } \\
\text { Jawab kepada } \\
\text { Kaisar }\end{array}$ & $\begin{array}{l}100 \% \text { Milik } \\
\text { Publik } \\
\text { Bertanggung } \\
\text { Jawab kepada } \\
\text { Parlemen }\end{array}$ & $\begin{array}{l}100 \% \text { Milik } \\
\text { Publik } \\
\text { Bertanggung } \\
\text { Jawab kepada } \\
\text { Presiden }\end{array}$ \\
\hline Finansial & $\begin{array}{l}80 \% \text { luran TV } \\
10 \% \text { Budget } \\
\text { Negara } \\
10 \% \\
\text { Komersial/ } \\
\text { lainnya }\end{array}$ & $\begin{array}{l}90 \% \text { Iuran TV } \\
10 \% \text { Budget } \\
\text { Negara }\end{array}$ & $\begin{array}{l}90 \% \text { Budget } \\
\text { Negara } \\
10 \% \\
\text { Komersial/ } \\
\text { lainnya }\end{array}$ & $\begin{array}{l}90 \% \text { Budget } \\
\text { Negara } \\
10 \% \\
\text { Komersial/ } \\
\text { lainnya }\end{array}$ \\
\hline $\begin{array}{l}\text { Program } \\
\text { Siaran }\end{array}$ & $\begin{array}{l}\text { Informasi, } \\
\text { Edukasi, dan } \\
\text { Hiburan }\end{array}$ & $\begin{array}{l}\text { Informasi, } \\
\text { Edukasi, } \\
\text { Budava dan } \\
\text { Hiburan }\end{array}$ & $\begin{array}{l}\text { Informasi, } \\
\text { Edukasi, } \\
\text { Budaya dan } \\
\text { Hiburan }\end{array}$ & $\begin{array}{l}\text { Informasi, } \\
\text { Edukasi, } \\
\text { Budaya dan } \\
\text { Regional }\end{array}$ \\
\hline SDM & $\begin{array}{l}70 \% \text { In House } \\
30 \% \text { by } \\
\text { Commisioning }\end{array}$ & $\begin{array}{l}100 \% \text { Pegawai } \\
\text { Negara }\end{array}$ & $\begin{array}{l}100 \% \text { Pegawai } \\
\text { Negara }\end{array}$ & $\begin{array}{l}69 \% \text { PNS } \\
31 \% \text { PBPNS/ } \\
\text { Tenaga } \\
\text { Kontrak }\end{array}$ \\
\hline Teknologi & $\begin{array}{l}\text { FTA Digital } \\
\text { Radio Digital } \\
\text { Media baru }\end{array}$ & $\begin{array}{l}\text { FTA Digital } \\
\text { Radio Digital } \\
\text { Media baru }\end{array}$ & $\begin{array}{l}\text { FTA Digital } \\
\text { Radio Digital } \\
\text { Media Baru }\end{array}$ & $\begin{array}{l}\text { FTAAnalog } \\
\text { FTA Digital } \\
\text { Media baru }\end{array}$ \\
\hline
\end{tabular}

Gambar 4. Tabel Perbandingan Lembaga Penyiaran Publik Sumber: Dokumentasi Direktorat Penyiaran Kominfo (2020) 
Dari tabel perbandingan lembaga penyiaran publik 4 negara terlihat dari aspek kelembagaan baik BBC Inggris, NHK Jepang, ABC Australia, maupun TVRI sama-sama 100 persen milik publik dan bertanggung jawab kepada kepala negara. Tapi dari segi finansial, BBC dan NHK sama-sama lebih mengandalkan iuran dari publik ketimbang anggaran negara dan pendapatan komersial/lainnya, adapun ABC Australia dan TVRI lebih mengandalkan anggaran negara. Dari segi program siaran, keempatnya memiliki kemiripan mencakup informasi dan edukasi, tapi TVRI memiliki penguatan dari segi budaya yang dikaitkan dengan aspek regional. Kemudian dari segi SDM, mayoritas pegawai BBC adalah karyawan sendiri, NHK dan ABC seluruhnya pegawai negara, adapun TVRI mayoritas diisi PNS tapi sekitar sepertiganya masih calon PNS/ tenaga kontrak. Terakhir, BBC, NHK, dan ABC sudah memiliki teknologi digital terbaru, adapun TVRI sedang masa transisi dari analog ke digital.

Menyangkut keuangan, UU No. 32 Tahun 2002 Pasal 46 Ayat (8) menyatakan, "Waktu siaran iklan niaga untuk Lembaga Penyiaran Swasta paling banyak 20\% (dua puluh per seratus), sedangkan untuk Lembaga Penyiaran Publik paling banyak 15\% (lima belas per seratus) dari seluruh waktu siaran”. Selain aturan yang membatasi porsi maksimal iklan lembaga penyiaran publik, slot iklan TVRI sendiri belum terisi penuh karena masih banyak program acara TVRI minim khalayak sehingga pengiklan tidak tertarik. "Yang mau memasang iklan itu hanya kementerian dan lembaga pemerintah sebagai program mereka" (Wimbarti, Wawancara. 21 Mei 2020).

Meski sumber pembiayaan di luar APBN dimungkinkan, hal itu tidak dapat dijalankan karena peraturan pemerintah menyangkut instrumen pelaksanaannya belum ada. Selain itu, TVRI pernah menikmati iuran televisi tidak lama setelah mengudara pada 1962. Ketika televisi swasta bermunculan era 1990-an, iuran televisi tidak ada lagi. Jika sekarang diberlakukan, masyarakat akan melihat terlebih dulu manfaatnya karena memiliki banyak pilihan media, baik media massa maupun media online.

\section{Tanggung Jawab Sosial TVRI}

TVRI memiliki 1 stasiun pusat dan 29 stasiun penyiaran daerah (TVRI, 2019b). Jangkauan siaran TVRI hingga pelosok wilayah Indonesia lebih unggul ketimbang stasiun-stasiun televisi swasta yang hanya seputar wilayah yang menjadi pengukuran rating dari lembaga riset Nielsen.

"Di Papua nggak bisa nonton lain, cuma bisa TVRI. Di Ambon dan Flores mau nonton apa, cuma TVRI aja yang bisa ditonton... Dalam memenuhi kewajiban TVRI sebagai televisi publik, TVRI memberikan siaran publik sebanyak 56.000 jam pertahun. Acara lokal disiarkan 4 jam sehari di 29 stasiun milik TVRI. TVRI juga memberikan siaran ilmu pengetahuan dan budaya pada primetime." (Putra, Wawancara. 9 Maret 2020).

Berdasarkan TVRI Media Profile (TVRI, 2020), 29 stasiun daerah TVRI menjangkau titik terdepan Indonesia. TVRI memiliki stasiun Banda Aceh di sebelah barat hingga stasiun Jayapura di sebelah timur, dari stasiun Manado di sebelah utara hingga stasiun Kupang di sebelah selatan. TVRI menyatakan siarannya mampu menjangkau Sabang-Merauke dan Miangas-Rote.

Poin pertama teori pers tanggung jawab sosial adalah media menerima dan memenuhi kewajiban tertentu dalam masyarakat. Upaya TVRI dipuji Komisi Penyiaran Indonesia (KPI). "Bagus, TVRI paling banyak Iklan layanan masyarakat tentang Covid-19. Sebelum Covid-19, mereka melakukan kewajiban informasi dan pendidikan" (Suprio, Wawancara. 12 Juni 2020). Dapat dikatakan, dengan tayangan yang merata hingga pelosok Indonesia, kewajiban TVRI akan penayangan ilmu pengetahuan dan budaya pada jam primetime dan iklan layanan sosial sudah dipenuhi.

Pada poin kedua teori pers tanggung jawab sosial menyangkut profesionalitas kerja. Segi 
profesionalitas TVRI dapat dilihat dari independensi pada setiap pemberitaan atau informasi yang diberikan. Apni Jaya Putra menyatakan bahwa pada Pemilihan Presiden 2019 dan Pilkada serentak TVRI memberikan porsi berimbang dalam pemberitaan dan acara debat para kandidat (Putra, Wawancara. 9 Maret 2020).

Independensi TVRI dalam pemberitaan atau informasi dapat dilihat dari tidak adanya sanksi KPI. "Saat ini TVRI belum ada sanksi terkait keinformasian, kebenaran, ketepatan, dan juga keseimbangan. Jadi kalau melihat berita TVRI itu kan berita berimbang bahkan ketika pemilu juga berimbang" (Suprio, Wawancara. 12 Juni 2020).

Poin ketiga teori pers tanggung jawab sosial berkaitan dengan kemandirian lembaga. Sebagai lembaga penyiaran publik kepentingan TVRI merupakan kepentingan negara dan melayani kepentingan masyarakat. Kominfo menyatakan bahwa independensi TVRI menyangkut konten, berdasarkan UU No. 32 Tahun 2002, TVRI harus independen dan tidak memihak satu sama lainnya (Kurnia, Wawancara. 24 Juni 2020).

Dengan demikian, TVRI lebih memiliki kemandirian menentukan konten ketimbang zaman Orde Baru yang banyak diintervensi kalangan pemerintahan.

Poin keempat teori pers tanggung jawab sosial berkaitan dengan tanggung jawab pers menjaga ketertiban umum. "Itu masuk ke dalam white paper kita (buku panduan penyiaran TVRI). Policy arahan Dewan Pengawas kepada Direksi itu disusun semuanya menyangkut sifatnya hal-hal seperti itu." (Putra, Wawancara. 9 Maret 2020). Supra Wimbarti menambah, prinsip tayangan TVRI adalah memberitahu kebenaran tapi tidak terkandung sesuatu yang meresahkan masyarakat, seperti berita kriminal tidak terlalu banyak diekspos dan program keagamaan yang menjaga keharmonisan (Wimbarti, Wawancara. 21 Mei 2020).

Upaya TVRI menjaga ketertiban umum juga diakui KPI. "Sejauh ini TVRI tidak ada tayangan yang rasialis. TVRI juga tidak ada pemberitaannya kriminalitas terlalu vulgar" (Suprio, Wawancara. 12 Juni 2020). Dapat dikatakan, dengan white paper sebagai panduan, pemberitaan TVRI berhasil menjaga ketertiban umum.

Poin kelima teori pers tanggung jawab sosial menyangkut pluralisme dan mencerminkan kebhinekaan.

"Masalah tanggung jawab kebhinekaan sudah dilakukan dengan mengacu pada pedoman yang dibuat oleh Dewan Pengawas. Salah satu contohnya, saya punya gambar kerusuhan di Manokwari itu lebih awal daripada televisi lain, saya tahan sampai semua verifikasi selesai. Bawahan bilang "Pak, ini breaking news", saya bilang "No, jangan dinaikkan. Yang saya marah kalau kalian tidak mem-breaking news bencana alam, karena kalian harus menyelamatkan ribuah orang... Soal hak jawab itu kita berikan tapi hampir nggak ada problem." (Putra, Wawancara. 9 Maret 2020)

KPI menyatakan TVRI memiliki paling sedikit pelanggaran dan pengaduan masyarakat dibandingkan stasiun televisi lainnya (Suprio, Wawancara. 12 Juni 2020). Keunggulan TVRI dalam hal jumlah stasiun yang tersebar di berbagai provinsi di Indonesia juga membuat TV Publik ini mampu mengangkat keanekaragaman masyarakat Indonesia.

"TVRI adalah satu-satunya stasiun televisi yang setiap pekannya menayangkan siaran dari lima agama di Indonesia, yang berdurasi 60 menit, secara bergilir. Untuk hak menjawab itu juga kita utamakan sebagaimana diatur dalam kode etik jurnalistik. Jika terjadi kekeliruan penayangan dan ada pihak-pihak yang ingin meluruskan, sudah beberapa kali masyarakat memakai hak jawab." (Samal, Wawancara. 11 Mei 2020).

Komisi I DPR RI mengakui TVRI memelihara kebhinekaan dimulai dari secara internal hingga ke pengembangan program. TVRI sebagai lembaga penyiaran publik berjalan pada rel kebangsaan, motonya pun media pemersatu bangsa, jadi informasi yang disampaikannya pun mempersatukan bukan memecah-belah (Nursanty, Wawancara. 5 Juni 2020).

Upaya TVRI menjaga kebhinekaan dan memberikan hak jawab juga dinyatakan KPI. 
"TVRI sudah bersifat pluralis dan mencerminkan kebinekaan dengan memberikan kesempatan berbagai sudut pandang dan hak untuk menjawab." (Suprio, Wawancara. 12 Juni 2020).

Dengan demikian, TVRI dapat dikatakan menjaga kebhinekaan di masyarakat. TVRI berupaya mengangkat keanekaragaman adat, budaya, dan agama di Indonesia secara berimbang. Bahkan, demi menjaga keutuhan dan kepentingan bangsa, TVRI dapat mengesampingkan nilai aktualitas berita.

Poin terakhir teori pers tanggung jawab sosial berkaitan dengan upaya mengakomodir tuntutan masyarakat. Sebagai TV Publik, TVRI harus terbuka pada aspirasi masyarakat untuk memperoleh tayangan bermutu dan menarik. Apni Jaya Putra berpendapat bahwa peran dewan pengawas mesti direposisi bukan sebagai eksekutorial tapi menjadi representasi masyarakat. Ia membandingkan dengan Dewan Penyiaran BBC di Inggris ketika mengubah white paper, lembaga ini mengumumkan ke publik dan melakukan public hiring selama 3 tahun hanya untuk mengganti konsep bagaimana mereka harus berpindah ke platform digital, menentukan pedoman dan standar etik digital. Demikian juga Advisory Council ABC Australia melakukan public hiring secara berkala 3 kali dalam setahun (Putra, Wawancara. 9 Maret 2020).

Peran dewan pengawas yang lebih berfokus ke internal TVRI ketimbang penyambung aspirasi publik diakui juga oleh salah satu anggota dewan pengawas. "Dewan pengawas masih kurang di dalam melibatkan publik untuk menilai kinerja TVRI. Seharusnya, kami lebih banyak keluar mendengarkan masyarakat, tapi dewan pengawas selama ini terlalu nguplek-nguplek ke bawah." (Wimbarti, Wawancara. 21 Mei 2020)

KPI lebih menyoroti kondisi masyarakat yang banyak diantaranya tidak berharap lagi terhadap TVRI sehingga rasa memilikinya menjadi kurang.

"Jujur saja nih saya di Jakarta, saya nggak tahu kalau ke daerah. Orang Jakarta itu memang sedikit banget yang nonton TVRI. Saya tanya ke teman saya, keluarga saya, 'Ngapain nonton TVRI? Jadul banget sih' gitu rata-rata orang Jakarta. Coba ke Jepang, NHK itu luar biasa, BBC itu luar biasa banget, TV publik di Jepang atau di Korea Selatan itu sangat diminati oleh warga negaranya. Sekarang kan pertanyaannya adalah bagaimana kemudian menimbulkan harapan ke TVRI? TVRI harus membuka diri terhadap keluhan masyarakat, termasuk kota besar Jakarta, yang banyak nggak berharap lagi ke TVRI." (Suprio, Wawancara. 12 Juni 2020)

Hasil Survei Indeks Kualitas Program dan Berita TVRI 2019 oleh Puslitbang TVRI dan Provetic terhadap 1740 responden secara online menunjukkan citra "jadul" masih melekat pada TVRI. Berdasarkan top impression terhadap TVRI, "Jadul" berada diurutan ketujuh (6\%) setelah "Berita" (21\%), "Indonesia" (12\%), "Nasionalis" (11\%), "Mendidik" (9\%), dan "Terpercaya" (8\%) dan "Pertama" (6\%). Kategori selanjutnya "Menarik" (5\%), "Informatif" (5\%), dan "Budaya" (4\%) (TVRI, 2019b). Dari top impression yang ada, TVRI sebetulnya digambarkan responden memiliki citra lembaga penyiaran publik yang baik. Tapi citra "jadul" dan top impression lain yang berkategori serius memerlukan strategi yang tepat untuk meraih khalayak yang sudah terbiasa disuguhi berbagai program acara hiburan dari stasiun televisi lain.

Dapat dikatakan, TVRI belum memiliki saluran untuk mengakomodir tuntutan masyarakat. Jika sejumlah TV Publik di negara-negara maju terdapat dewan penyiaran yang menjadi representasi masyarakat, maka dewan pengawas TVRI lebih menjadi pengawas kerja direksi. Padahal sebagai TV Publik yang menggunakan APBN masyarakat memiliki hak dilibatkan dalam public hearing untuk pemenuhan aspirasinya bagi peningkatan standar prestasi TVRI. 
DOI: $10.24198 /$ jkj.v5i1.31893

\section{Pembahasan}

Media massa merupakan media yang ditujukan ke khalayak luas, sehingga sejatinya, mengacu pada Habermas, menjadi ruang publik (public sphere). Namun ruang publik di media terdesak oleh kepentingan pemilik modal yang menjadikan khalayak sebagai target pasar. Di tengah perkembangan media yang lebih melayani kepentingan modal, lembaga penyiaran publik diharapkan dapat menjadi ruang publik untuk menyalurkan aspirasi dan mencerdaskan masyarakat. Penelitian Masduki (2018) menemukan, kebijakan lembaga penyiaran publik di Inggris merupakan bentuk kewajiban negara dalam menyediakan ruang publik, tapi di Indonesia tekanan dari para pemilik modal mencoba membatasi reformasi lembaga penyiaran publik melalui tata kelola regulasi.

Di tengah kondisi itu, TVRI sebagai lembaga penyiaran publik berupaya menjalankan misi dan tanggung jawab sosialnya. Analisis kaitan misi dan tanggung jawab sosial yang dijalankan TVRI tergambar pada matrik 1. Pada misi pertama, TVRI menerima dan memenuhi kewajiban dengan menayangkan killer content yang infomatif dan edukatif untuk menarik minat masyarakat menonton TVRI. Profesionalitas kerja TVRI ditunjukkan melalui penyajian setiap informasi yang mempertahankan independensi. Dari kemandirian lembaga, anggaran yang masih tergantung APBN membuat TVRI memiliki dana terbatas untuk membuat program acara berkualitas. Untuk menjaga ketertiban umum, TVRI memiliki white paper sebagai panduan. TVRI mengangkat keanekaragaman adat, budaya, dan agama di Indonesia secara berimbang dalam program acaranya.

Misi kedua TVRI, dengan keuangan terbatas, TVRI berupaya memenuhi kewajiban tayangan informatif dan edukatif. Independensi TVRI dalam menayangkan informasi juga tidak terganggu. Tapi anggaran yang masih tergantung APBN berpengaruh perbedaan pendapat dewan direksi dan dewan pengawas dalam RKAT dan RKA-KL. Dalam memenuhi tanggung jawab sosialnya, TVRI berupaya menjaga ketertiban umum serta mengangkat pluralisme dan kebhinekaan. Tapi dalam kompetisi media TVRI belum dapat bersaing secara optimal.

Selanjutnya misi ketiga, upaya TVRI ditunjang penyiaran berbasis digital dan multiplatform. Aplikasi TVRI Klik menjangkau khalayak tanpa dibatasi geografis. TVRI lebih maju dalam jumlah transmisi digital dibandingkan TV swasta. Dalam misi keempat, TVRI berupa memenuhi kewajibannya yang mulai didukung keberadaan tenaga kreatif generasi muda. Tapi keterbatasan anggaran membuat TVRI kesulitan meningkatkan kesejahteraan dan pengembangan diri karyawan muda. Tenaga kreatif generasi muda yang belum lama direkrut juga masih perlu ditanamkan budaya organisasi baru secara berkelanjutan.

Pada misi kelima, upaya TVRI didukung kemampuan pengelolaan aset secara optimal dan tepat guna. Tapi TVRI memiliki kelemahan dalam manajemen administrasi, aturan yang membatasi pengembangan, dan masalah birokrasi. Kelemahan manajemen administrasi dewan direksi, serta persoalan aturan dan birokrasi menyebabkan konflik dewan pengawas dan dewan direksi. Pengelolaan aset mulai meningkatkan kualitas tayangan, tapi TVRI sebagai TV Publik belum memiliki saluran untuk melibatkan publik mengontrol kinerjanya. Effendy (2014) menyatakan, lembaga penyiaran publik memiliki potensi dalam menyediakan ruang publik agar warga masyarakat mampu berinteraksi secara seimbang dan dinamis dengan kekuatan negara dan pasar. Masyarakat juga diharapkan proaktif mendesakkan kepentingan publik kepada lembaga penyiaran publik melalui pelibatan mereka dalam perencanaan program siaran, supervisi, dan evaluasi.

Terakhir, misi keenam, TVRI melakukan berbagai kerja sama untuk distribusi program dan partnership yang berguna untuk memenuhi kewajibannya. Berdasarkan Undang No. 32 Tahun 2002, porsi maksimal iklan TVRI memang lebih rendah ketimbang stasiun televisi 
swasta, tapi slot iklan yang tersedia sendiri belum terisi penuh yang menunjukkan banyak program acara TVRI masih minim khalayak sehingga pengiklan tidak tertarik. Instrumen pelaksanaan sumber pembiayaan di luar APBN dan iklan juga belum ada sehingga TVRI masih tergantung pembiayaan dari APBN. Dalam hal iuran publik, diperlukan pengkajian lebih komprehensif karena penolakan masyarakat akan tinggi jika mereka belum menjadikan TVRI sebagai saluran televisi sehari-hari. Wibawa, Afifi, \& Prabowo (2014) mengusulkan TVRI perlu mengembangkan model bisnis yang menjadikannya sebagai multiplekser melalui penyediaaan frekuensi untuk televisi komunitas dan televisi pendidikan yang lebih berorientasi kepada publik.

Dalam implementasi misi TVRI terlihat lembaga penyiaran publik ini sudah berupaya memenuhi tanggung jawab sosial dan berkompetisi meraih khalayak, tapi terkendala dua faktor: regulasi dan konsolidasi internal. Faktor regulasi menyangkut Undang No. 32 Tahun 2002 yang memberikan dewan pengawas kedudukan yang bersifat eksekutorial internal mengawasi kerja dan memberhentikan direksi ketimbang bertindak sebagai representasi masyarakat. Hal itu berdampak konflik struktural dewan pengawas dan dewan direksi yang potensial terus berulang. Hubungan dewan pengawas dan dewan direksi yang lebih disibukkan urusan birokrasi internal membuat publik tidak memiliki saluran untuk mengontrol kinerja TVRI. Implikasinya, rasa memiliki publik terhadap TVRI masih kecil. Khalayak generasi lama belum kembali menjadikan TVRI sebagai saluran TV Keluarga. Meskipun TVRI Klik berupaya mendekatkan diri ke generasi muda, kalangan ini belum menjadikannya sebagai stasiun televisi utama. Memang terdapat sejumlah program acara unggulan yang menarik pemirsa, tapi splash dari content killer belum banyak menyebar ke program-program acara lain.

Kendala regulasi juga membatasi TVRI mencari sumber pembiayaan sehingga berdampak pada upaya meningkatkan kualitas program acara, sarana dan prasarana, serta kesejahteraan dan pengembangan karyawan. Temuan Masduki (2018) menyebutkan bahwa proses lahirnya UU No. 32 Tahun 2002 selama 1998-2002 berlangsung intens di mana tiga aktor: pemerintah, industri dan masyarakat sipil terlibat. Tapi industri memiliki lebih banyak sumber daya untuk menciptakan tekanan terhadap pembuat kebijakan agar mereka lebih dominan di pasar. Secara formal, UU tersebut mengakui lembaga penyiaran publik sebagai badan independen dan milik publik, tapi tidak ada kebijakan yang tepat untuk memastikan perbaikan berkelanjutan dari pengelolaannya. Dari sisi kepentingan publik, regulasi tersebut sangat lemah.

Smith (2012) menyatakan, pemerintah perlu mendefinisikan dulu apa yang diharapkan dari lembaga penyiaran publik kemudian dimasukkan ke dalam kebijakan penyiaran, undangundang dan ketentuan peraturan. Tanpa kebijakan dan peraturan yang baik, tidak mungkin lembaga penyiaran publik dapat beroperasi secara maksimal untuk kepentingan masyarakat.

Kemudian faktor konsolidasi internal menyangkut manajemen administrasi dan belum mapannya budaya organisasi baru yang dirintis sejak Direktur Utama Helmy Yahya melakukan reformasi TVRI. Persoalan manajemen administrasi muncul karena TVRI terikat rambu-rambu aturan dan birokrasi yang berbeda dengan stasiun TV swasta, sehingga ketika pimpinan TVRI diisi orang-orang yang berpengalaman lama di stasiun TV swasta maka upaya perubahan harus memperhatikan aturan dan birokasi yang ada.

Studi penelitian tentang budaya dan kinerja perusahaan menunjukkan perusahaan yang memiliki fokus pada budaya meningkatkan pendapatannya signifikan sehingga berinvestasi dalam budaya organisasi memiliki efek yang tak terbantahkan pada produktivitas (Cui \& $\mathrm{Hu}$, 2012). Budaya organisasi TVRI untuk mengejar prestasi tinggi yang belum mapan menjadi tantangan tersendiri agar perubahan kinerja TVRI yang berjalan terus meluas dan berkelanjutan, termasuk di kalangan tenaga kreatif generasi muda rekrutan baru. 
Tabel 1. Matrik Misi TVRI dan Tanggung Jawab Sosial Pers

\begin{tabular}{|c|c|c|c|c|c|c|}
\hline \multirow[b]{2}{*}{$\begin{array}{l}\text { TANGGUNG } \\
\text { JAWAB } \\
\text { SOSIAL PERS }\end{array}$} & \multicolumn{6}{|c|}{ MISI TVRI } \\
\hline & Program Acara & $\begin{array}{l}\text { Tata Kelola } \\
\text { Keuangan }\end{array}$ & $\begin{array}{c}\text { Penyiaran } \\
\text { Berbasis } \\
\text { Digital dan } \\
\text { Multiplatform }\end{array}$ & $\begin{array}{c}\text { Tata Kelola } \\
\text { SDM }\end{array}$ & $\begin{array}{c}\text { Tata kelola } \\
\text { Kelembagaan, } \\
\text { Tata Kerja, dan } \\
\text { Pengelolaan } \\
\text { Aset }\end{array}$ & $\begin{array}{c}\text { Pemanfaatan } \\
\text { Aset dan Bisnis }\end{array}$ \\
\hline $\begin{array}{l}\text { Menerima dan } \\
\text { memenuhi } \\
\text { kewajiban }\end{array}$ & $\begin{array}{l}\text { Menayangkan } \\
\text { killer content } \\
\text { yang infomatif } \\
\text { dan edukatif } \\
\text { untuk } \\
\text { menarik minat } \\
\text { masyarakat }\end{array}$ & $\begin{array}{l}\text { Dengan keuangan } \\
\text { terbatas, TVRI } \\
\text { berupaya } \\
\text { memenuhi } \\
\text { kewajiban } \\
\text { tayangan } \\
\text { informatif dan } \\
\text { edukatif }\end{array}$ & $\begin{array}{l}\text { Kewajiban } \\
\text { infomatif } \\
\text { dan edukatif } \\
\text { ditunjang } \\
\text { penyiaran } \\
\text { berbasis } \\
\text { digital dan } \\
\text { multiplatform }\end{array}$ & $\begin{array}{l}\text { Kewajiban } \\
\text { informatif } \\
\text { dan edukatif } \\
\text { mulai diisi } \\
\text { tenaga kreatif } \\
\text { generasi muda }\end{array}$ & $\begin{array}{l}\text { Kewajiban } \\
\text { informatif } \\
\text { dan edukatif } \\
\text { didukung } \\
\text { pengelolaan aset } \\
\text { optimal dan tepat } \\
\text { guna }\end{array}$ & $\begin{array}{l}\text { Kewajiban } \\
\text { informatif dan } \\
\text { edukatif melalui } \\
\text { kerjasama } \\
\text { untuk distribusi } \\
\text { program dan } \\
\text { partnership }\end{array}$ \\
\hline $\begin{array}{l}\text { Profesionalitas } \\
\text { Kerja }\end{array}$ & $\begin{array}{l}\text { Independensi } \\
\text { pada setiap } \\
\text { informasi yang } \\
\text { disajikan }\end{array}$ & $\begin{array}{l}\text { Meski keuangan } \\
\text { terbatas, } \\
\text { independensi } \\
\text { informasi TVRI } \\
\text { tidak terganggu }\end{array}$ & $\begin{array}{l}\text { Independensi } \\
\text { informasi } \\
\text { TVRI melalui } \\
\text { penyiaran } \\
\text { digital dan } \\
\text { multiplatform }\end{array}$ & $\begin{array}{l}\text { Independensi } \\
\text { informasi } \\
\text { TVRI mulai } \\
\text { diisi tenaga } \\
\text { kreatif } \\
\text { generasi muda }\end{array}$ & $\begin{array}{l}\text { Independensi } \\
\text { informasi } \\
\text { didukung } \\
\text { kemampuan } \\
\text { pengelolaan aset } \\
\text { optimal dan tepat } \\
\text { guna }\end{array}$ & $\begin{array}{l}\text { Independensi } \\
\text { informasi } \\
\text { TVRI didukung } \\
\text { kerjasama } \\
\text { distribusi } \\
\text { program dan } \\
\text { partnership }\end{array}$ \\
\hline $\begin{array}{l}\text { Kemandirian } \\
\text { lembaga }\end{array}$ & $\begin{array}{l}\text { TVRI memiliki } \\
\text { dana terbatas } \\
\text { membuat } \\
\text { program acara } \\
\text { berkualitas }\end{array}$ & $\begin{array}{l}\text { Anggaran yang } \\
\text { bergantung } \\
\text { APBN } \\
\text { berpengaruh } \\
\text { konsolidasi } \\
\text { internal }\end{array}$ & $\begin{array}{l}\text { Di tengah } \\
\text { anggaran } \\
\text { terbatas, } \\
\text { transmisi digital } \\
\text { TVRI lebih } \\
\text { unggul dan ada } \\
\text { TVRI Klik. }\end{array}$ & $\begin{array}{l}\text { Keterbatasan } \\
\text { anggaran } \\
\text { berdampak } \\
\text { pada } \\
\text { kesejahteraan } \\
\text { dan } \\
\text { pengembangan } \\
\text { karyawan } \\
\text { muda } \\
\end{array}$ & $\begin{array}{l}\text { Manajemen } \\
\text { administrasi } \\
\text { lemah, aturan } \\
\text { yang membatasi, } \\
\text { dan masalah } \\
\text { birokrasi. }\end{array}$ & $\begin{array}{l}\text { Instrumen } \\
\text { pelaksanaan } \\
\text { sumber } \\
\text { pembiayaan } \\
\text { di luar APBN } \\
\text { belum ada dan } \\
\text { iklan sedikit }\end{array}$ \\
\hline $\begin{array}{l}\text { Menjaga } \\
\text { Ketertiban } \\
\text { Umum }\end{array}$ & $\begin{array}{l}\text { White paper } \\
\text { sebagai panduan } \\
\text { program acara } \\
\text { TVRI }\end{array}$ & $\begin{array}{l}\text { Berupaya } \\
\text { menjaga } \\
\text { ketertiban umum } \\
\text { di tengah kondisi } \\
\text { keuangan terbatas }\end{array}$ & $\begin{array}{l}\text { Menjaga } \\
\text { ketertiban } \\
\text { umum dengan } \\
\text { penyiaran } \\
\text { berbasis } \\
\text { digital dan } \\
\text { multiplatform }\end{array}$ & $\begin{array}{l}\text { Menjaga } \\
\text { ketertiban } \\
\text { umum } \\
\text { didukung } \\
\text { tenaga kreatif } \\
\text { generasi muda }\end{array}$ & $\begin{array}{l}\text { Menjaga } \\
\text { ketertiban } \\
\text { umum didukung } \\
\text { pengelolaan aset } \\
\text { secara optimal } \\
\text { dan tepat guna }\end{array}$ & $\begin{array}{l}\text { Menjaga } \\
\text { ketertiban } \\
\text { umum didukung } \\
\text { kerjasama } \\
\text { distribusi } \\
\text { program dan } \\
\text { partnership }\end{array}$ \\
\hline $\begin{array}{l}\text { Pluralisme } \\
\text { dan Cermin } \\
\text { Kebhinekaan }\end{array}$ & $\begin{array}{l}\text { TVRI berupaya } \\
\text { mengangkat } \\
\text { keanekaragaman } \\
\text { adat, budaya, dan } \\
\text { agama secara } \\
\text { berimbang }\end{array}$ & $\begin{array}{l}\text { Mengangkat } \\
\text { pluralisme dan } \\
\text { kebhinekaan di } \\
\text { tengah kondisi } \\
\text { keuangan terbatas }\end{array}$ & $\begin{array}{l}\text { Mengangkat } \\
\text { pluralis-me dan } \\
\text { kebhinekaan } \\
\text { melalui } \\
\text { penyiaran } \\
\text { digital dan } \\
\text { multiplatform }\end{array}$ & $\begin{array}{l}\text { Mengangkat } \\
\text { pluralisme dan } \\
\text { kebhinekaan } \\
\text { didukung } \\
\text { tenaga kreatif } \\
\text { generasi muda }\end{array}$ & $\begin{array}{l}\text { Mengangkat } \\
\text { pluralisme dan } \\
\text { kebhinekaan } \\
\text { didukung } \\
\text { pengelolaan aset } \\
\text { optimal dan tepat } \\
\text { guna }\end{array}$ & $\begin{array}{l}\text { Mengangkat } \\
\text { pluralisme dan } \\
\text { kebhinekaan } \\
\text { didukung } \\
\text { kerjasama } \\
\text { distribusi } \\
\text { program dan } \\
\text { partnership }\end{array}$ \\
\hline $\begin{array}{l}\text { Akomodir } \\
\text { Masyarakat }\end{array}$ & $\begin{array}{l}\text { Splash dari killer } \\
\text { content TVRI } \\
\text { belum banyak } \\
\text { menyebar ke } \\
\text { program acara } \\
\text { lain }\end{array}$ & $\begin{array}{l}\text { Dengan anggaran } \\
\text { terbatas, TVRI } \\
\text { belum dapat } \\
\text { bersaing secara } \\
\text { optimal di } \\
\text { masyarakat }\end{array}$ & $\begin{array}{l}\text { TVRI unggul } \\
\text { dalam jumlah } \\
\text { transmisi digital } \\
\text { dan ada aplikasi } \\
\text { TVRI Klik }\end{array}$ & $\begin{array}{l}\text { Tenaga kreatif } \\
\text { generasi } \\
\text { muda perlu } \\
\text { ditanamkan } \\
\text { budaya baru } \\
\text { organisasi }\end{array}$ & $\begin{array}{l}\text { Kualitas } \\
\text { tayangan dengan } \\
\text { pengelolaan } \\
\text { aset, tapi TVRI } \\
\text { belum melibatkan } \\
\text { publik }\end{array}$ & $\begin{array}{l}\text { Slot iklan belum } \\
\text { terisi penuh } \\
\text { karena masih } \\
\text { banyak program } \\
\text { acara minim } \\
\text { khalayak }\end{array}$ \\
\hline
\end{tabular}

(Sumber: Hasil Pengolahan Peneliti) 
Volume 05 Nomor 01 Tahun 2021

DOI: $10.24198 / j k j . v 5 i 1.31893$

\section{SIMPULAN}

Di tengah perkembangan stasiun televisi swasta dan media online yang cenderung mengejar keuntungan, TVRI sebagai lembaga penyiaran publik memiliki tanggung jawab untuk memberikan arah bagi perkembangan positif di masyarakat. Upaya memenuhi tanggung jawab sosial dan kompetisi meraih khalayak tercermin dari visi TVRI yang dituangkan dalam enam misinya. Di era Direktur Utama Helmy Yahya berbagai terobosan dilakukan untuk memenuhi tanggung jawab sosial sekaligus meningkatkan kemampuan bersaing meraih khalayak. TVRI sudah berupaya memenuhi tanggung jawab sosialnya tapi terkendala dua faktor, yakni regulasi dan konsolidasi internal.

Pertama, faktor regulasi, UU No. 32 Tahun 2002 yang memberikan dewan pengawas kedudukan lebih kuat dan mengontrol kerja dewan direksi perlu direvisi. Kedudukan dewan pengawas harus direposisi sebagai representasi masyarakat yang menampung aspirasi karena penggunaan dana APBN harus dipertanggung jawabkan kepada publik. Jika porsi maksimal iklan lembaga penyiaran publik tetap dibedakan dengan lembaga penyiaran swasta, diperlukan kompensasi penambahan anggaran dari APBN. Selain itu, instrumen pembiayaan lain sebagai turunan UU tersebut juga harus ada sebagai upaya menumbuhkan kemandirian TVRI. TVRI juga perlu mengembangkan model bisnis yang menyediakan frekuensi untuk televisi komunitas dan televisi pendidikan. Kedua, menyangkut konsolidasi internal, manajemen administrasi internal TVRI perlu diperbaiki melalui check and recheck dengan rambu-rambu aturan dan birokrasi lembaga penyiaran publik. Untuk mengembangkan budaya organisasi baru, perekrutan tenagatenaga muda kreatif perlu dilanjutkan dan menggantikan karyawan-karyawan lama yang tidak mau berkembang agar budaya organisasi yang mengejar prestasi tinggi dapat meluas dan berkelanjutan. Diperlukan penguatan bidang pengelolaan sumber daya manusia untuk pengembangan diri karyawan secara terprogram dan peningkatan kesejahteraannya.

\section{DAFTAR PUSTAKA}

Cui, X., \& Hu, J. (2012). A literature review on organization culture and corporate performance. International Journal of Business Administration, 3(2), 28-37. https://doi.org/10.5430/ ijba.v3n2p28

De Fretes, M., \& Kaligis, R. A. W. (2018). Implementasi teori Pers tanggung jawab sosial dalam pemberitaan TVRI pusat. CoverAge: Journal of Strategic Communication, 9(1), 26-34. https://doi.org/10.35814/coverage.v9i1.1115

Detoni, M. (2016). The public service broadcasting and the construction of a public sphere. Comunicação e Sociedade, 30(December 2016), 39-54. https://doi.org/10.17231/ comsoc.30(2016).2484

Effendy, R. (2014). Mengurai potensi ruang publik Lembaga Penyiaran Publik dalam upaya demokratisasi masyarakat lokal. Reformasi, 4(2), 111-123. Diakses dari https://jurnal. unitri.ac.id/index.php/reformasi/article/view/57

Firnandi, A. (2017). Polemik penyiaran publik di Indonesia: Potret kondisi TVRI. Jurnal Komunikasi Dan Media, 2(1), 94-106. https://doi.org/10.33884/commed.v2i1.239

Hutagalung, I. (2013). Dinamika sistem Pers di Indonesia. Interaksi: Jurnal Ilmu Komunikasi, 2(2), 53-60. https://doi.org/10.14710/interaksi.2.2.156-163

Indriani, D., Fahmi, I., \& Yusuf, A. M. (2017). Perancangan sistem evaluasi kinerja Direktorat Pemberitaan LPP-TVRI dengan pendekatan Balanced Scorecard (BSC). Jurnal Aplikasi Bisnis Dan Manajemen, 3(1), 47-58. https://doi.org/10.17358/jabm.3.1.47

Iswara, A. J. (2019). Helmy Yahya dan formula anti-aging untuk TVRI. Diakses dari goodnewsfromindonesia.id website: https://www.goodnewsfromindonesia. 
id/2019/10/07/helmy-yahya-dan-formula-anti-aging-untuk-tvri

Kaifi, B. A., Nafei, W. A., Khanfar, N. M., \& Kaifi, M. M. (2012). A multi-generational workforce: Managing and understanding millennials. International Journal of Business and Management, 7(24), 88-93. https://doi.org/10.5539/ijbm.v7n24p88

Masduki. (2018). Public broadcasting reform in the transitional society: The case of Indonesia. Jurnal Komunikasi Indonesia, 6(2), 112-119. https://doi.org/10.7454/jki.v6i2.8916

McQuail, D. (2010). Mass communication theory. London: Sage Publication.

Nugroho, Y., Putri, D. A., \& Laksmi, S. (2012). Memetakan lanskap industri media kontemporer di Indonesia. Jakarta: Centre for Innovation Policy and Governance.

Rachmiatie, A. (2006). Konsistensi penyelenggaraan RRI dan TVRI sebagai Lembaga Penyiaran Publik. Mediator: Jurnal Komunikasi, 7(2), 281-292. https://doi. org/10.29313/mediator.v7i2.1277

Ravi, B. K. (2012). Media and social responsibility: A critical perspective with special reference to television. Academic Research International, 2(1), 306-325. Diakses dari http://www. savap.org.pk/journals/ARInt./Vol.2(1)/2012(2.1-35).pdf

Septiantoro, B., Agus, R., Gultom, G., \& Octavian, A. (2018). Pengaruh media nasional terhadap media warfare. Jurnal Studi Komunikasi Dan Media, 22(2), 89-108. https:// doi.org/10.31445/jskm.2018.220201

Smith, E. (2012). A road map to public service broadcasting. Kuala Lumpur: Asia-Pasific Broadcasting Union (ABU).

TVRI. (2019a). Monitor. Majalah Internal TVRI No 122 Edisi Spesial. Diakses dari http://staging.tvri.go.id/assets/ppid/122---MONITOR-MARET-2019-SPECIALEDITION-c5428.pdf

TVRI. (2019b). Survei indeks kualitas program dan berita TVRI. Jakarta. Diakses dari http:// staging.tvri.go.id/assets/ppid/Survei-Indeks-Kualitas-Program-dan-Berita-TVRI.pdf

TVRI. (2020). TVRI media profile. Diakses dari http://tvri.go.id

Wibawa, A., Afifi, S., \& Prabowo, A. (2014). Model bisnis penyiaran televisi digital di Indonesia. Jurnal Ilmu Komunikasi, 8(2), 117-130. Diakses dari http://jurnal.upnyk. ac.id/index.php/komunikasi/article/view/74

Young, S. J., Sturts, J. R., Ross, C. M., \& Kim, K. T. (2013). Generational differences and job satisfaction in leisure services. Managing Leisure, 18(2), 152-170. https://doi.org/10.10 80/13606719.2013.752213 